\title{
The Islamic Microfinance System And Its Ultimate Impact On The Poor In Bauchi Metropolis In The Context Of Socio-Economic Challenges
}

https://doi.org/10.21272/sec.5(1).95-101.2021.

Hashim Sabo Bello, ORCID: https://orcid.org/0000-0002-3954-9020

$\mathrm{PhD}$, Department of Business Administration and Management, School of Management Sciences, Abubakar Tatari Ali Polytechnic Bauchi, Bauchi state, Nigeria

\section{Shamsuddeen Abubakar}

Department of Business Administration and Management, School of Management Sciences, Abubakar Tatari Ali Polytechnic Bauchi, Bauchi state, Nigeria

\section{Sunusi Abdulkadir Fateh}

Department of Banking and Finance, School of Management Studies, Abubakar Tatari Ali Polytechnic, Bauchi, Bauchi State, Nigeria

\begin{abstract}
One of the conditions for providing social services to the population, reducing the differentiation of their incomes, as well as reducing poverty is to provide equal access to financial services for all segments of the population. Despite high unemployment and a significant number of poor people, only about a few thousand Nigerians today use Islamic microfinance services. The main purpose of this study is to study the impact of the Islamic microfinance system on the financial situation of the population. The study is based on the principles of the theory of positivism. Methods of deduction, statistical analysis, and survey served as methodological tools. The authors of the article developed a structured questionnaire, the analysis of which allowed to analyze the attitude of citizens to Islamic microfinance services. A representative sample of citizens of the metropolis Bauchi with different levels of wealth, age and gender was selected for the study. According to the results of the survey, the development of special microcredit programs for low-income people allowed to finance the start of their own business, thus providing their own and household members' employment. The main factors hindering the development of microfinance in Muslim countries are the high level of non-repayment of borrowed funds, imperfect infrastructure, the presence of Sharia bans on certain types of financial transactions. The results of the study showed the need for an active information campaign aimed at explaining the benefits of using macro-financial services and their accessibility for low-income citizens, as well as expanding the network of microfinance institutions throughout the metropolis. These measures will create conditions for the development of small business in the country, and as a consequence reduce poverty and reduce the number of unemployed in the country.
\end{abstract}

Keywords: awareness, Bauchi metropolis, impact, islamic microfinance, poor.

JEL Classification: G19, M21.

Cite as: Bello, H.S., Abubakar, S., Fateh, S.A. (2021). The Islamic Microfinance System And Its Ultimate Impact On The Poor In Bauchi Metropolis In The Context Of Socio-Economic Challenges. SocioEconomic Challenges, 5(1), 95-101. https://doi.org/10.21272/sec.5(1).95-101.2021.

Received: 11.01 .2021

Accepted: 11.02.2021

Published: 30.03 .2021

Copyright: (C) 2021 by the authors. Licensee Sumy State University, Ukraine. This article is an open access article distributed under the terms and conditions of the Creative Commons Attribution (CC BY) license (https:// creativecommons.org/licenses/by/4.0/). 


\section{Introduction}

Microfinance is often defined as financial services for poor and low-income clients offered by different types of service providers. The term is often used more narrowly to refer to loans and other services from providers that identify themselves as "microfinance institutions" (MFIs). These institutions commonly tend to use new methods developed over the last 30 years to deliver very small loans to unsalaried borrowers, taking little or no collateral. These methods include group lending and liability, pre-loan savings requirements, gradually increasing loan sizes, and an implicit guarantee of ready access to future loans if present loans are repaid fully and promptly (Project Concern International, 2016). It is imperative for Islamic banking scholars and practitioners to understand consumers' patronage towards Islamic banking products (Abedifar, et al., 2015; Majid, \& Zulhanizar, (2015). It's a known fact that the findings from the banking industry relate that the MFIs are different from commercial banks. First, MFIs pursue the double bottomline objectives of financial sustainability and social outreach and hence differ from commercial banks. Credit risk and diversification potentially affect both financial performance and MFIs' ability to fulfil their social objective of reaching out to more low-income customers. Second, MFIs' customers (low-income people and microenterprises) are normally excluded by traditional commercial banks because they are considered risky (due to factors like where they live and what they do), yet such customers are the focus of MFIs. Third, the loans MFIs give to their customers are smaller and without collateral security while commercial banks' loans are larger and collateralized. Fourth, most MFIs (e.g., 62 percent of MFIs in our sample) are non-shareholder organizations (NGOs and cooperatives/credit unions) (Misra and Lee, 2007) which compared to shareholder owned organizations have slacker governance and allow more risk-taking by CEOs (Galema, et al., 2012). From a global perspective, microfinance organizations envision a world in which lowincome households have permanent accesses to a range of high quality and affordable financial services offered by a range of retail providers to finance income-producing activities, build assets, stabilize consumption, and protect against risks (Project Concern International, 2016).Islamic Microfinance means micro financing through interest free modes to the financially deprived and poor people to generate economic activities and making them self-employed for the ultimate economic prosperity. As per the latest research of the Centre of Excellence in Islamic Microfinance of AlHuda CIBE, the global Islamic Microfinance volume has reached at US \$1 billion with persistent growth and serving about 1.3 million beneficiaries but the share of Islamic Microfinance by less than $1 \%$ of overall volume of Islamic Finance (US \$1.3 trillion), unveils its misfortune (Zubair, 2014). There is substantial potential in deploying Islamic finance instruments to promote inclusive growth, reduce inequality and accelerate poverty reduction (Alawode, 2018). As in Nigeria, Microfinance institutions were established to enhance and provide the flow of financial services to meet the need of poor and low income groups who engages in agricultural sector and non-farm activities such as trading, tailoring, weaving, blacksmithing, agro-processing and transportation, etc., through an appropriate menus for both rural and urban poor (Adamu, et al., 2010). Islamic microfinance is not just mere microfinance from a conventional sense, accepting deposits and lending are the core competencies of conventional microfinance to have the maximum spread between the two. Whereas Islamic microfinance focus on profit/loss sharing by using the funds on economic generating, investing and trading activities to make a profit and share that profit with all the depositors and shareholders, whilst protecting the fabric of our society without engaging in activities prohibited and harmful to the society. There is broad scholarly support for expanding and developing Islamic microfinance across Muslims countries. While conventional microfinance is well developed, with wide reach across the globe, Islamic microfinance has yet to penetrate its potential market. According to a survey by the Consultative Group to Assist the Poor, the total number of Islamic microfinance accounts and clients in 2007 was 380,000, which made up only $0.5 \%$ of the microfinance industry's total outreach (Karim, 2008). There are strong arguments for its expansion. An estimated $72 \%$ of people living in Muslim-majority countries, such as Somalia, can be defined as "unbanked" because they do not have access to traditional financial services offering lending and savings components (Karim, 2008). Furthermore, of the world's approximately 1.7 billion people who live below the poverty line, $44 \%$ reside in Muslim countries (The Nation, 2011). In Somalia, the majority of its ten million citizens fall into this category. These figures indicate that there are millions of people who could benefit from Islamic microfinance. The 2009 case study of Pakistan emphasizes that combining the Islamic social principle of caring for the less fortunate with microfinance's power to provide financial services access to the poor has the potential to reach out to millions more people (Akhter, et al., n.d.). In support of expanding Islamic Micro Finance Institutions, it is frequently noted that microfinance as a poverty alleviation tool is well aligned with the principles of Islam. "Islam views poverty to be a curse to be eradicated through productive efforts... there is 
therefore a convergence between the objectives of Islam and the avowed aims of 'best practices' microfinance" (Obaidullah, 2007). Specifically, the concept of helping the poor is directly supported under the third of the five pillars of Islam; zakat, meaning giving support to the needy. The Five Pillars of Islam: Firstly, Testimony of faith (shahada); Secondly, Prayer (salat); Thirdly, Giving support for the needy (zakat); Fourthly, Fasting (saum) in the month of Ramadan; and Fifthly, The pilgrimage (hajj) to Mecca. Many rural areas are disadvantaged in Muslim countries particularly in central Asia, sub-Sahara Africa, and MENA region. They have no proper access to the formal lending and to conventional or Islamic financing. Moreover, the lending institutions are not even well-spread enough to reach out to the needy. Private and foreign banks that seek to maximize their profits are concentrating only on the urban cities. Poor projects are left only to public banks because of the high risk that is associated with lending to the poor or micro producers. Given the rate of high poverty among these low income groups and the unavailability of collateralization mechanism, lending to this group is normally associated with greater risk as reflected in the banks' high non-performing loans in some countries like Nigeria. Because majority of people in Muslim countries are Muslim by birth, Islamic Microfinance is one way to meet the financial needs of these people. However, this will enable them to achieve better financial inclusions even for the non-Muslim poorest minority living among them. Islamic microfinance can provide small loans for the poor people or people with good expertise without any start-up capital. Unlike conventional microfinance, Islamic microfinance generated its vision from Islamic worldview and therefore, it grants finance to the needy for self-employment based on objectives of Islamic law (maqasid al-sharaiah), whilst protecting the fabric of our society without engaging in activities prohibited and harmful to the society. In Nigeria, where there is an Islamic microfinance bank and Islamic stock market index the likes of Tijjarah Microfinance Bank Limited and Lotus Islamic Index in Bauchi and Lagos (Nigeria) respectively, the target market is confined to the Muslims community only. As if Islamic microfinance is confined to the Muslims and not for the non-Muslims, who are looking for alternatives to the conventional modes of banking and financing.

\section{Method/Approach}

The study adopts a bit of the positivism theory. The positivism theory provides the basis of explanation, permit the anticipation of phenomena, predict their occurrence and therefore allow them to be controlled (Collis and Hussey, 2009). The study moved from theory to data analysis explaining causal relationships between variables. According to the literature available, research based on Islamic microfinance in Nigeria virtually absent or had not been published yet. However, sufficient literature on Islamic microfinance is only available from other countries. Conceptual framework will be developing based on literature and pilot survey. Research strategy is developed to plan and answer the research questions. After having considered several research strategies such as experiment, case studies, etc., a survey was opted for to carry out the research, which is a popular and common strategy in business and management research. It links to the deductive approach as well. This research study was an academic research, which had to be completed with limited available resources: both time and money. The practical survey strategy adopted produced adequate data through the administration of the designed questionnaire on the target population. Data collected through the questionnaire provided standard data allowing easy comparison. To facilitate high response rate, the questionnaire instrument was administered personally. The structured questionnaire was distributed to the various categories of respondents and besides, convenience sampling was used where the researcher selects the most accessible population members. Since it is extremely expensive in practice to collect data from all the parameters, a convenience sampling and judgement techniques were used. Sample size for this research work includes selected businessmen/women with ultra-poor income in Bauchi metropolis. The rationale behind selecting both businessmen and women is to have divergent ideas across the study area. A structured questionnaire was distributed to the respondents in Bauchi metropolis; thereby convenience sampling technique was used. The data collected were analyzed using frequency tables, percentages and simple tabulation. A combination of both descriptive and inferential statistics was used as the method of data analysis.

\section{Result and Discussion}

The focus of this research article aimed at evaluating the relative divergence perceptions of respondents on the relevance of Islamic micro modes of financing in Bauchi metropolis. Following this, the research study was made to be exploratory in nature as it analyzed the respondents' perceptions about the Islamic microfinance in Bauchi 
metropolis from the ethical context. Thus this study resorted to the respondents' categories in the affirmative (Yes) and those not (No); a method used in other studies where the psychometric nature of a Likert scale would be misleading as the respondents for this study are colloquially known to be not-so-literate.

Table 1 below presents the respondents' perception about the implications of Islamic microfinance on poor individuals

Question 1: What are your perceptions on the main implications of Islamic microfinance on the poor individuals?

Table 1. Analyses of Responses on implications of Islamic microfinance on the poor individuals

\begin{tabular}{|l|l|c|c|c|c|c|c|}
\hline 1. & Respondents' thoughtfulness on the point of view of Islamic microfinance and its bearing on the poor individuals \\
\hline S/N & Questions & Yes & $\%$ & No & $\%$ & Total & Total $(\%)$ \\
\hline i. & $\begin{array}{l}\text { Poverty is not created by poor people but it is created by the } \\
\text { institutions and policies which surround them. }\end{array}$ & 28 & 76 & 9 & 24 & 37 & 100 \\
\hline i. & $\begin{array}{l}\text { Poor people have skills that remain unutilized or under-utilized and } \\
\text { therefore it's not the lack of skills that makes them poor. }\end{array}$ & 27 & 73 & 10 & 27 & 37 & 100 \\
\hline i. & $\begin{array}{l}\text { Loans offer people the opportunity to take initiatives in business or } \\
\text { agriculture to make earnings that enable them to pay off debt. }\end{array}$ & 23 & 62 & 14 & 38 & 37 & 100 \\
\hline r. & $\begin{array}{l}\text { Charity is not an answer to poverty but it only helps poverty to } \\
\text { continue thereby creates dependency and takes away an } \\
\text { individual's initiative. }\end{array}$ & 21 & 57 & 16 & 43 & 37 & 100 \\
\hline
\end{tabular}

Source: Field study (2020).

The interpretation of the results revealed that the responses obtained from the questions asked on Respondents' awareness of the relevance of the main products of Islamic microfinance. Islamic Microfinance means micro financing through interest free modes to the financially deprived and poor people to generate economic activities and making them self-employed for the ultimate economic prosperity. Hence, from the results obtained it show that majority of the respondents believed that the benefits of microfinance are wider than just giving people access to finance and borrowers benefit from feeling more empowered and being financially included in society because of access to microfinance. The Islamic microfinance targets the poorest of the poor, with a particular emphasis on women, and the objective has been to promote financial independence among the poor. Tijarah microfinance Bank situated in Bauchi metropolis, for instance, gives its borrowers freedom to pursue a better future using the skills they already possess in the best way they can. This study found that seasonal agricultural loans and leaseto-own agreements for equipment and livestock help the poor establish better agriculture.

Table 2 below presents the respondents' perception about the acceptability challenges of Islamic microfinance in the microfinance industry.

Question 2: What are your perceptions on the acceptability challenges of Islamic microfinance in the microfinance industry?

Table 2. Analyses of Responses on acceptability challenges of Islamic microfinance

\begin{tabular}{|c|c|c|c|c|c|c|c|}
\hline \multirow{2}{*}{$\begin{array}{l}1 \\
\mathrm{~S} / \mathrm{N} \\
\end{array}$} & \multicolumn{7}{|c|}{$\begin{array}{l}\text { To determine the respondents' thoughtfulness on acceptability challenges of the Islamic microfinance by the ultra- } \\
\text { poor individuals }\end{array}$} \\
\hline & Questions & Yes & $\%$ & No & $\%$ & Total & Total $(\%)$ \\
\hline i. & $\begin{array}{l}\text { Does Islamic Microfinance education make Islamic Microfinance } \\
\text { acceptable to the ultra-poor individuals? }\end{array}$ & 21 & 57 & 16 & 43 & 37 & 100 \\
\hline ii. & $\begin{array}{l}\text { Instant acceptability caused by lack of awareness is an impediment } \\
\text { to the Islamic microfinance? }\end{array}$ & 27 & 73 & 10 & 27 & 37 & 100 \\
\hline iii. & $\begin{array}{l}\text { Does the issue of religious consciousness cause challenges to the } \\
\text { Islamic microfinance practice? }\end{array}$ & 25 & 68 & 12 & 32 & 37 & 100 \\
\hline iv. & $\begin{array}{l}\text { Few specialized institutions for Islamic Microfinance doings are } \\
\text { one of the hurdles for promotion of the industry in Bauchi } \\
\text { metropolis? }\end{array}$ & 31 & 84 & 6 & 16 & 37 & 100 \\
\hline
\end{tabular}

Source: Field study (2020). 
The interpretation of the results in the table 2 above revealed that the responses obtained from the questions asked on respondents' consciousness of the main challenges of Islamic microfinance. As according to the expert view it is stated that the Islamic Microfinance education is the ultimate way to make Islamic Microfinance practicing and let the people aware of the Islamic Microfinance on global canvas for its acceptability. Therefore, it's observed there are few specialized institutions for the education of Islamic Microfinance in particular. In addition, from the results obtained it show that majority of the respondents believed that the other challenges to the Islamic microfinance behind successful execution is instant acceptability caused by lack of awareness. Furthermore, the study observed that though the Islamic microfinance is widely believed to be a subset of the socially responsible investment which in reality represents a good example of alternative ethical financing but still there is inadequate religious consciousness to fasten the basic objective of Islam being the liberation of people from all kind of material and doctrinal slavery. Moreover, the inadequate number of specialized institutions in Islamic Microfinance, particularly, is another crucial fact in Islamic Microfinance Industry, which is one of the hurdles for the promotion of the industry as well. There is an immediate need to initiate comprehensive degree programs on Islamic Microfinance globally.

As a matter of fact, if we look into the main challenges of Islamic microfinance, the lack of awareness and education fall on the top. Islamic Microfinance Industry is facing lot of criticism in different aspects e.g. acceptability of Islamic Finance because of lack of awareness, education, religious consciousness and few numbers of specialized institutions. The study concurs with Zubair (2014) that the expensive education of Islamic microfinance is also a discouraging factor for the Islamic Microfinance learners which should be subsidized and funded by Donor agencies e.g. IFC, World Bank and IDB etc. On the global poverty index, the Muslim World has a $46 \%$ concentration while the World Muslim population is $26 \%$ (Zubair, 2014). As a matter of fact, the Islamic Microfinance can potentially be used for poverty alleviation by social awareness programmes through proper channels and educationists of Islamic Micro Finance realizing its importance and optimal results.

\section{Conclusion and recommendation}

In conclusion, it should be noted that the Islamic Microfinance particularly as in Tijarah Microfinance Bank Limited (in the Bauchi metropolis) have helped many people in Bauchi metropolis by lifting the poor individuals out of poverty through providing small loans to those lacking access to traditional financial services or funding opportunities. The Tijarah Microfinance have grown popular over the past few years because they offer impoverished people access to funds that can be used to develop small businesses, provide regular income and financial resources to underserved markets. As such, Islamic microfinance is an important tool not just to minimize the impacts of poverty, but also to promote business development. According to Zekri (2013), Microfinance programs have become a key component of the strategies of the struggle against poverty. The used financial innovations, whether the group loans, the use of non-financial services or dynamic incentive mechanisms as means to combat poverty, have increased the interest of governments and researchers. Microfinance includes a wide range of financial services such as the micro-credits, the small savings, the micro-insurance and the money transfers, which are aimed at the impoverished populations. This sector is experiencing an extremely rapid growth throughout the world.

Islamic microfinance can be used to mitigate the negative impact of the high unemployment rate among the youth in Muslim countries. Evidence has shown that the rate of unemployment is skyrocketing in the world among the adult and youth at same time in most Muslim countries. Islamic microfinance can be used as a quick response, targeted to finance small entrepreneurship such as Small and Medium-sized Enterprises (SMEs). Hence, Islamic microfinance can be used effectively to overcome the problem of hyper unemployment and the challenges facing SMEs in accessing suitable finance in Muslim countries. As the case of other Muslims countries, the Sudanese experience showed that Islamic microfinance has a positive impact on income generating activities. In addition, Islamic microfinance used to finance graduate students as a part of the unemployed youth sector in Sudan (Elzahi, 2015).

Despite the many benefits, microfinance institutions face a range of challenges that limit their reach, especially in predominantly Muslim countries. Some challenges facing Islamic micro-finance in Muslim countries is high cost and the riskiness of financing poor borrowers. This stems from the small size of their finances, the remote 
residential areas of the poor from the urban cities, and their uncollateralized risk. Thus, the projects executed by the poor are always of small scale in nature and they always lived in very remote and even some times, primitive areas in Muslims countries. In addition, Muslims countries only recently recognized the essentiality of microfinance as a tool of empowering low income group, reducing the problem of unemployment, and elevating poverty. Also, the weakness of the Islamic microfinance infrastructures includes the limited spread of Islamic financial institutions and the relevant financial regulations, and the unavailability of popular Islamic micro finance agencies or effective program in these countries (Elzahi, 2015).

One more challenge in providing Islamic microfinance services is the inadequate number of specialized institutions in Islamic Microfinance industry. While conventional microfinance is successful in many countries with Muslim populations, including Nigeria, with the proliferation of Microfinance institutions modeled on none Islamic Sharia-compliant. There remain many people who couldn't benefit from microfinance and some vast majority of Muslims across the metropolis refrains from using conventional microfinance services because the element of interest is considered repugnant to Islamic law (sharia). Thus, this call for the increasing recognition of the role that Islamic Sharia-compliant microfinance could play in cyclical economy and thereby reducing poverty in Muslim communities. Lastly, this study recommended for proliferation of more Islamic microfinance institutions to quickly facilitate more access funding to borrowers by disrupting established networks of power and patronage in the interest-based microfinance. This could help achieve the goal of having a healthy income statement and better financial inclusions in the midst of Muslims and non-Muslim poorest minorities living in the metropolis and to some extent will bring economic prosperity and social harmony/security that the city needed today.

\section{Funding: self-funded.}

Author contribution: conceptualization, Hashim Sabo Bello, Shamsuddeen Abubakar, Sunusi Abdulkadir Fateh; data curation, Hashim Sabo Bello; formal analysis, Hashim Sabo Bello, Shamsuddeen Abubakar, Sunusi Abdulkadir Fateh; funding acquisition, Hashim Sabo Bello, Shamsuddeen Abubakar, Sunusi Abdulkadir Fateh; investigation, Hashim Sabo Bello, Shamsuddeen Abubakar, Sunusi Abdulkadir Fateh; methodology, Hashim Sabo Bello, Shamsuddeen Abubakar, Sunusi Abdulkadir Fateh; project administration, Hashim Sabo Bello, Shamsuddeen Abubakar, Sunusi Abdulkadir Fateh; resources, Hashim Sabo Bello, Shamsuddeen Abubakar, Sunusi Abdulkadir Fateh; software, Hashim Sabo Bello, Shamsuddeen Abubakar, Sunusi Abdulkadir Fateh; supervision, Hashim Sabo Bello, Shamsuddeen Abubakar, Sunusi Abdulkadir Fateh; validation, Hashim Sabo Bello, Shamsuddeen Abubakar, Sunusi Abdulkadir Fateh; visualization, Hashim Sabo Bello, Shamsuddeen Abubakar, Sunusi Abdulkadir Fateh; writing - original draft, Hashim Sabo Bello, Shamsuddeen Abubakar, Sunusi Abdulkadir Fateh; writing - review \& editing, Hashim Sabo Bello, Shamsuddeen Abubakar, Sunusi Abdulkadir Fateh.

\section{References}

1. Abdullah, J. (2014). Talent Development in the Islamic Finance Industry: Needed or Not. Available at: http://coaching.Yurizk.com/yblc2014/. Retrieved on $26^{\text {th }}$ June, 2014.

2. Abedifar, P., Ebrahim, S. M., Molyneux, P., \& Tarazi, A. (2015). Islamic banking and finance: Recent empirical literature and directions for future research. Journal of Economic Surveys, 29 (4), 637- 670. Doi: http://dx.doi.org/10.1111/joes.12113.

3. Akhter, W., Nadeem, A. and Syed, K. A. J. (Undated). Islamic Micro Finance and Poverty Alleviation: a Case of Pakistan. https://akhuwat.org.pk/islamic-micro-finance-and-poverty-alleviation-a-case-of-pakistan/.

4. Alawode, A., Hafiz, A.A. and Aviles, A.M. (2018). Sustainable Development Goals and the role of Islamic finance. Available at: http://blogs.worldbank.org/eastasiapacific/sustainable-development-goals-and-roleislamic-finance. Retrieved on 26th May, 2019.

5. Elzahi, S.A.S. (2015). Islamic Microfinance: Moving beyond Financial Inclusion. European Scientific Journal, April 2015 Edition, 11(10). Available at: https://eujournal.org/index.php/esj/article/view/5427.

6. Book of Luke/Bible, New Testament/King James Version. Internet: Available at: www.readbookonline.net/read/16668/43574. Retrieved on 25/05/2013. 
7. Collis, J. and Hussey, R. (2009). Business Research: A Practical Guide for Undergraduate and Postgraduate Students. $3{ }^{\text {rd }}$ Edition. New Delhi: Palgrave Macmillan. Available at: https://www.amazon.com/BusinessResearch-Practical-Undergraduate-Postgraduate/dp/1403992479.

8. Galema, R., Robert, L. and Roy, M. (2012). Do powerful CEOs determine microfinance performance? Journal of Management Studies, 49(4), 718-742. Available at: DOI: 10.1111/j.1467-6486.2012.01046.x.

9. Ikram, M.T. (2014). Challenges and Resolves for Islamic Finance Education: A Practitioner's perspective. Available at: http://coaching. Yurizk.Com/yblc2014/. Retrieved on 26/06/2014.

10. Karim, N., Michael, T. and Xavier, R. (2008). Islamic Microfinance: An Emerging Market Niche" CGAP Focus Note, no. 49 (August). Available at: http://www.cgap.org/publications/islamicmicrofinance-. Retrieved on $2^{\text {nd }}$ May, 2017.

11. Kristiano, A. (2013). Filling a Niche for Islamic Banking. Daily Trust Newspaper, 31(81). Monday, April 1. Abuja: Media Trust Ltd. pp. 19. Available at: https://www.cgap.org/sites/default/files/CGAP-Focus-NoteIslamic-Microfinance-An-Emerging-Market-Niche-Aug-2008.pdf.

12. Majid, M. S. A., \& Zulhanizar, S. (2015). An Empirical Study On The Patronage Behaviour of Islamic Bank's Customers in Aceh, Indonesia. In The 6th Seminar \& Conference on Business \& Technology in ICT Industry (SCBTII) (p. 27). Available at: https://umexpert.um.edu.my/public view.php?type=publication\&row=NTg2NzY\%3D.

13. Misra, R. and Lee, N. (2007). Primary agricultural society linkage: The best remote self-help groups in India can do? Small Enterprise Development, 18(1), 25-36. Available at: https://www.findevgateway.org/casestudy/2007/03/primary-agricultural-society-linkage-best-rural-remote-self-help-groups-india.

14. Obaidullah, M. (2007). Islam, Poverty and Micro Finance Best Practices. Available at: http://instituteofhalalinvesting.org/content/Islam_and_poverty.pdf. Retrieved on 02/05/2017

15. Project Concern International (2016). Microfinance in Africa. Available at: www.PCIGlobal.org. Retrieved on $12 / 20 / 2016$.

16. The Nation. (2011). $4 \mathrm{pc}$ of Poverty-hit Live in Muslim Countries. Available at: http://www.nation.com.pk/pakistan-news-newspaper-daily-english-online/business/25-Apr-2011/44pc-ofpovertyhit--live-in-Muslim-countries. Retrieved on 02/05/2017.

17. Zekri, S (2013). Towards an inclusive vision of micro finance in Tunisia. Journal of Business Studies Quarterly, 5(2). Available at: https://www.jstor.org/stable/43503855.

18. Zubair, M. M. (2014). Islamic Microfinance education: the critical need, opportunity and way forward. Available at: http://coaching.Yurizk.Com/yblc2014/. Retrieved on 26/06/2014. 